\title{
Physicochemical Analysis of Soil Samples from Donga, Bali and Mutum-Biyu Local Government Areas in Taraba State, Nigeria.
}

\author{
Efi, U. J. \\ National Biotechnology Development Agency, Abuja \\ Tutuwa, Jummai A. \\ National Biotechnology Development Agency, Abuja \\ Samuel A. G. \\ Nasarawa State University, Keffi \\ Nuhu Iliya \\ Nasarawa State University, Keffi \\ DOI: 10.29322/IJSRP.10.02.2020.p9826 \\ http://dx.doi.org/10.29322/IJSRP.10.02.2020.p9826
}

\begin{abstract}
Soil samples from Donga, Bali and Mutum-Biyu Local Government Areas were evaluated chemically for the following metals ions, $\mathrm{K}, \mathrm{Na}, \mathrm{Ca}, \mathrm{Mg}, \mathrm{Mn}, \mathrm{Pb}, \mathrm{Cu}, \mathrm{Fe}, \mathrm{Zn}$, Ni and $\mathrm{Cr}$. Nitrogen was also evaluated. The physical parameters were also studied: pH, colour, density, specific density, conductivity and texture. K and Na were determined by flame photometry, the rest of the 9 metals were determined using atomic absorption photometry methods. Nitrogen was determined by Kjeldal $\sim$ athod. The results showed the soil sampled to contain varying amount of element in decreasing order of $\mathrm{K}>\mathrm{Ca}>\mathrm{Na}>\mathrm{N}>\mathrm{Fe}>\mathrm{Mg}>\mathrm{Mn}>\mathrm{Ni}>\mathrm{Gr}>\mathrm{Pb}$. The $\mathrm{pH}$ values ranged from 4.10 to 6.90 , thus presenting the soiis as acidic while the conductivity values ranged from $0.31 \mathrm{ps} / \mathrm{cm}$ to $2.20 \mathrm{ps} / \mathrm{cm}$. The density and specific gravity ranged from $1.12 \mathrm{~g} / \mathrm{cm} 2$ to $2 \mathrm{~S} 3 \mathrm{~g} / \mathrm{cm} 3$ and 1.11 to 2.74 , respectively. The soil samples were mostly.
\end{abstract}

Keywords: Physicochemical, Soil Chemistry, Heavy Metals and Soil Morphology

\section{Introduction}

Soil is defined as the material that forms the physical matrix of the earth crust (Kennedy, 1992). Soil is one of the most important natural resources (Brady, 2002). St assumes this importance through its position in the landscape and dynamic, physical and biologic functions. The general concept of soil varies according to the perspective of the discipline or occupation using soil as a resource. So far, the understanding of soil is incomplete despite the duration of mankind's dependence on soil and curiosity on it exploration of its diversity and dynamics continues to yield fresh discoveries and insight (Buol, 1973).

New avenues of soil research are needed to understand soil in the context of climate change, greenhouse gases and carbon sequestration 3revik, 2002). The interest in maintaining the plants biodiversity and in exploring $\mathrm{p}<$ ast cultures has also stimulated renewed interest in achieving a more defined understanding of soil (Brevik, 2002).

Geologists have a particular interest in the pattern of soil on the surface of the earth (Dooley, 2006). Soil texture, colour and chemistry often reflect the underlying geological patterned material and changes of soil types at geologic unit boundaries (Pielke, 2005). Soil consists of material and. organic matters, including living organisms, comprising the pedosphere, positioned at the interface of the lithosphere with the biosphere, atmosphere and hydrosphere (Pielke, 2005). Soil formation or pedogenesis, is the combined impact of physical, chemical, biological and anthropogenic process on soil parent material resulting in the formation of soil horizons (Nikiforoff, 2006).

\section{Materials and Methods}




\subsection{Study Setting and Design}

Three different farmlands were selected for this study. This farmlands includes: Donga, Bali and Mutum-Biyu Local Government Areas, the sampling was carried out at a distance of two (2) kilometers apart from $10 \mathrm{~km}$ in each of the four (4) cardinal directions (North, south, East West) respectively in each metropolis.

\subsection{Sample Collection and Pretreatment}

Most of our knowledge of soil chemistry comes from soil study. Soil study includes preliminarily soil mapping and sampling. The process was to determined the different soil types, soil elemental composition and other properties of the soil (Brady, 2002). Information were derived from physical geography and analysis of chemical elements, vegetation and land use pattern.

\subsection{Sampling}

In Donga, Bali and Mutum-Biyu Local Government Areas, the sampling was carried out at a distance of two (2) kilometers apart from $10 \mathrm{~km}$ in each of the four (4) cardinal directions (North, south, East West) respectively in each metropolis. Soil sampling was dugged at about $3 \mathrm{~cm}$ depth using a cutlass and a hoe for clearing the dried grasses and digging. Each of the soil samples in the four (4) cardinal directions was packaged in an air tight large envelope. The same method of sampling was used in the three (3) local government areas and there were a total of 60 soil samples.

\subsection{List of the Soil Samples}

In each metropolis and each of the four cardinal direction five (5) samples were collected and labelled N1 to N5 for the north direction, S1 to S5 for the south direction, E1 to E5 for the east direction and W1 to W5 for the west direction. The labels were contrasted by the first letters of names of the metropolis D, B and M, for Donga, Bali and Mutum-Biyu respectively. Soil samples location from Donga, Bali and Mutum -Biyu Local Government Area of Taraba State, Nigeria were denoted as;

\section{SAMPLES}

\begin{tabular}{ccccc}
\hline Location & North & South & East & West \\
& & & Total \\
\hline Donga L.G.A & DN1-DN5 & DS1-DS5 & DE1-DE5 & DW1-DW5 20 \\
Bali L.G. A & BN1-BN5 & BS1-BS5 & BE1 - BE5 & BW1 - BW5 20 \\
Mutum Biyu & MN1 -MN5 & MSI-MSS & ME1 - ME5 & MW1-MW5 20 \\
\hline
\end{tabular}

\subsection{Sample Analysis}

The physical properties of the soils determined were colour density, and specific density and texture while chemical elements were $\mathrm{N}$, $\mathrm{K}, \mathrm{Na}, \mathrm{Ca}, \mathrm{Mn}, \mathrm{Pb}, \mathrm{Fe}, \mathrm{Zn}, \mathrm{Ni}, \mathrm{Cr}$ and $\mathrm{Cu}$.

\section{$2.6 \mathrm{pH}$ and Conductiivity}

The $\mathrm{pH}$ were measured using 1:2 soil,water ratio with the the $\mathrm{pH}($ Mclean 1982).

The aqueous solutions of samples used for $\mathrm{pH}$ were also used for the conductimetry. The electrode was cleared with distilled water and wiped with tissue paper. The electrode was dipped into the sample solution and reading taking from the digital conductimeter. The unit of the scale is microsemen/centimetres (ps/cm).

\subsection{Density and Specific Gravity}

Density were measured by $10 \mathrm{~cm} 3$ cylinder weighed on an electronic weighing balance as $\mathrm{W} 1$ and then $5 \mathrm{~cm} 3$ of distilled water was poured into the cylinder and subsequent weight of both water and cylinder taken as

$\mathrm{W}_{2}$. The weight of water was obtained by deducting $\mathrm{w}_{1}$ from $\mathrm{W}_{2}$ i.e $\mathrm{W}_{2}$ - 
Wi. The density of water calculated as:-

Density of each soil sample $\left(\mathrm{p}_{\mathrm{s}}\right)=\frac{\text { Mass }}{\text { Volume }}=\underline{\Delta \mathrm{V}} \underline{\mathrm{g}}$

Specific gravity of each soil sample is $=\left(p_{\underline{s}}\right)$

$\left(\mathrm{p}_{\mathrm{w}}\right)$

\subsection{Colour and Texture}

Soil is the first impression one has when viewing soil (Bigham etal, 1993). Striking colours and contrasting pattern are likely to be noticed about soil, but colour has little effect on the behaviour and use of soil (Brady, 2002). An important exception to this statement is the fact that dark-coloured surface soil absorbed more solar energy than lighter- coloured soil and therefore warms up fastly (Brady, 2002). The main reason for studying soil colours is that they provide valuable clues to the nature of other soil properties and conditions (Brady, 1996). Soil texture is the proportion of different sized particles in a soil (Brady, 1996). Soil texture is critical for understanding of soil behaviour and management. Soil texture in the field is not readily subjected to change, so it is considered as a basic property of soil.

\section{Results}

The result of the heavy metal levels from the studied farmlands in Donga, Bali and Mutum-Biyu Local Government Areas are presented as follows;

The results of the physical properties are presented in table 1, while table 2 shows the chemical parameter values of the soil samples in all the samples sites.

\begin{tabular}{|c|c|c|c|c|c|c|c|}
\hline Samples & Colour & Notation & Texture & $\begin{array}{l}\text { Density } \\
\left(\mathrm{g} / \mathrm{cm}^{3}\right) \\
\end{array}$ & $\begin{array}{l}\text { Specific } \\
\text { gravity }\end{array}$ & $\mathrm{pH}$ & $\begin{array}{l}\text { Conductivity (x } \\
10 \sim^{3} \mathrm{pis} / \mathrm{cm} \text { ) }\end{array}$ \\
\hline $\mathrm{DN}_{1}$ & Dark brown & 7.3 YR $3 / 2$ & Fine & 1.54 & 1.59 & 6.90 & 1.55 \\
\hline $\mathrm{DN}_{2}$ & Light reddish brown & SYR 6/4 & Fine & 1.92 & 1.94 & 6.30 & 1.45 \\
\hline $\mathrm{DN}_{3}$ & Weak red & $2.5 \mathrm{YR} 5 / 4$ & Coarse & 1.66 & 1.69 & 5.20 & 1.23 \\
\hline $\mathrm{DN}_{4}$ & Pinkish gray & 7.5 YR $6 / 2$ & Coarse & 1.78 & 1.89 & 5.30 & 2.20 \\
\hline $\mathrm{DN}_{5}$ & Light red & SYR $5 / 8$ & Coarse & 1.16 & 1.22 & 4.10 & 1.39 \\
\hline $\mathrm{DS}_{1}$ & Black & 5 YR $2.5 / 2$ & Fine & 1.21 & 1.32 & 5.00 & 1.49 \\
\hline $\mathrm{DS}_{2}$ & Light reddish brown & $5 \mathrm{YR} 6 / 4$ & Fine & 1.32 & 1.41 & 4.90 & 1.36 \\
\hline $\mathrm{DSs}$ & Dark brown & 7.5 YR $4 / 4$ & Fine & 1.25 & 1.31 & 5.20 & 1.22 \\
\hline $\mathrm{DS}_{4}$ & Black & $5 \mathrm{YR} \mathrm{2.5/1}$ & Fine & 1.47 & 1.48 & 4.30 & 1.23 \\
\hline $\mathrm{DS}_{5}$ & Dark reddish gray & $5 \mathrm{YR} 4 / 2$ & Gravel & 1.72 & 1.77 & 5.80 & 131 \\
\hline $\mathrm{DE}_{1}$ & Reddish yellow & 5 YR $6 / 8$ & Coarse & 1.61 & 1.66 & 5.30 & 1.63 \\
\hline $\mathrm{DE}_{2}$ & Reddish brown & $5 \mathrm{YR} \mathrm{4/4}$ & Fine & $1 \mathrm{~J} 8$ & 1.87 & 5.30 & 1.51 \\
\hline $\mathrm{DE}_{3}$ & Dark reddish brown & $5 \mathrm{YR} 3 / 4$ & Coarse & 1.72 & 1.75 & 5.50 & 1.40 \\
\hline $\mathrm{DE}_{4}$ & Reddish gray & $5 \mathrm{YR} 5 / 2$ & Coarse & 1.75 & 1.76 & 5.40 & 1.04 \\
\hline $\mathrm{DW}_{1}$ & Reddish brown & $5 \mathrm{YR} \mathrm{4/4}$ & Fine & 1.47 & 1.52 & 5.50 & 1.09 \\
\hline
\end{tabular}




\begin{tabular}{|c|c|c|c|c|c|c|c|}
\hline SN 2250-3153 & & & & & & & \\
\hline $\mathrm{DW}_{2}$ & Brown & $5 \mathrm{YR} 5 / 4$ & Coarse & 1.28 & 1.34 & 5.20 & 1.29 \\
\hline $\mathrm{DW}_{3}$ & Reddish brown & $5 \mathrm{YR} 5 / 3$ & Coarse & 1.32 & 1.38 & 5.40 & 1.22 \\
\hline $\mathrm{DW}_{4}$ & Dark brown & 7.5 YR 4/4 & Fine & 1.25 & 1.28 & 4.20 & 1.39 \\
\hline $\mathrm{DW}_{5}$ & Strong brown & 7.5 YR $5 / 6$ & Fine & 1.28 & 1.29 & 5.60 & 1.39 \\
\hline $\mathrm{BN}_{1}$ & Strong brown & 7.5 YR 5/8 & Coarse & 1.17 & 1.19 & 6.00 & 1.49 \\
\hline $\mathrm{BN}_{2}$ & Light red & $10 \mathrm{R} 6 / 6$ & Gravel & 1.47 & 1.48 & 5.20 & 1.46 \\
\hline $\mathrm{BN}_{3}$ & Light red & $10 \mathrm{R} 6 / 8$ & Coarse & 1.45 & 1.46 & 5.00 & 1.45 \\
\hline $\mathrm{BN}_{4}$ & Light reddish brown & 5 YR 6/4 & Coarse & 1.51 & 1.54 & 5.60 & 1.56 \\
\hline $\mathrm{BN}_{5}$ & Reddish yellow & $5 \mathrm{YR} 6 / 6$ & Fine & 1.56 & 1.57 & 4.30 & 1.16 \\
\hline $\mathrm{BS}_{1}$ & Yellow red & 7.5 YR 5/8 & Coarse & 1.72 & 1.79 & 4.40 & 123 \\
\hline $\mathrm{BS}_{2}$ & Strong brown & 7.5 YR 5/6 & Coarse & 1.14 & 1.12 & 4.90 & 1.29 \\
\hline $\mathrm{BS}_{3}$ & Pinkish gray & 7.5 YR 6/2 & Coarse & 1.12 & 1.11 & 5.10 & 1.30 \\
\hline
\end{tabular}

Table 2: Soil contents of $\mathrm{N}, \mathrm{K}, \mathrm{Na}, \mathrm{Ca}, \mathrm{Mn}, \mathrm{Pb}, \mathrm{Fe}, \mathrm{Zn}, \mathrm{Ni}$ and $\mathrm{Cr}$ in the study area $\underline{(\mathrm{mg} / \mathrm{kg})}$

\begin{tabular}{|c|c|c|c|c|c|c|c|c|c|c|c|}
\hline $\begin{array}{l}\text { Sample } \\
\text { Locations }\end{array}$ & $\mathrm{N}$ & K & $\mathrm{Na}$ & $\mathrm{Ca}$ & $\mathrm{Mg}$ & $\mathrm{Mn}$ & $\mathrm{Pb}$ & $\mathrm{Fe}$ & $\mathrm{Zn}$ & $\mathrm{Ni}$ & $\mathrm{Cr}$ \\
\hline $\mathrm{DN}_{1}$ & 113 & 510 & 300 & 390 & 40 & 2 & 0.9 & 18 & 4 & 9 & 2 \\
\hline $\mathrm{DN}_{2}$ & 103 & 502 & 150 & 260 & 30 & 2 & 4 & 43 & 7 & 16 & 10 \\
\hline $\mathrm{DN}_{3}$ & 143 & 10 & 220 & 70 & 12 & 3 & 3 & 14 & 5 & 7 & 4 \\
\hline $\mathrm{DN}_{4}$ & 123 & 502 & 180 & 260 & 31 & 55 & 5 & 20 & 12 & 18 & ND \\
\hline $\mathrm{DN}_{5}$ & 83 & 500 & 180 & 330 & 41 & 35 & 2 & 15 & 5 & 11 & 4 \\
\hline $\mathrm{DS}_{1}$ & 109 & 125 & 240 & 200 & 28 & 12 & 0.9 & 12 & 12 & 3 & ND \\
\hline $\mathrm{DS}_{2}$ & 87 & 500 & 210 & 330 & 42 & 21 & 3 & 14 & 15 & 14 & 2 \\
\hline $\mathrm{DS}_{3}$ & 35 & 980 & 200 & 320 & 27 & 36 & 5 & 15 & 10 & 11 & ND \\
\hline $\mathrm{DS}_{4}$ & 31 & 550 & 300 & 200 & 29 & 3 & 4 & 46 & 12 & 14 & ND \\
\hline $\mathrm{DS}_{5}$ & 75 & 502 & 200 & 210 & 27 & 2 & 2 & 20 & 5 & 5 & ND \\
\hline $\mathrm{DE}_{1}$ & 109 & 620 & 280 & 140 & 19 & 8 & 3 & 18 & 3 & 18 & 4 \\
\hline $\mathrm{DE}_{2}$ & 186 & 680 & ND & 80 & 14 & ND & 2 & 14 & 2 & 5 & 2 \\
\hline $\mathrm{DE}_{3}$ & 163 & 460 & 150 & 60 & 30 & ND & 0.9 & 10 & 1 & 3 & ND \\
\hline $\mathrm{DE}_{4}$ & 143 & 460 & 250 & 170 & 18 & 3 & 8 & 28 & 12 & 18 & ND \\
\hline $\mathrm{DE}_{5}$ & 107 & 480 & 180 & 140 & 16 & 2 & 0.9 & 11 & 9 & 11 & 2 \\
\hline $\mathrm{DW}_{1}$ & 89 & 502 & 220 & 180 & 21 & 3 & 3 & 4 & 10 & 14 & ND \\
\hline $\mathrm{DW}_{2}$ & 107 & 580 & ND & 300 & 38 & 5 & 0.9 & 3 & 8 & 9 & 2 \\
\hline
\end{tabular}


International Journal of Scientific and Research Publications, Volume 10, Issue 2, February 2020 ISSN 2250-3153

$\begin{array}{rllllllllllr}\mathrm{DW}_{3} & 111 & 415 & \mathrm{~m} & 260 & 39 & 17 & 2 & 9 & 10 & 7 & 2 \\ \mathrm{DW}_{4} & 109 & 320 & 60 & 130 & 18 & 2 & 3 & 39 & 7 & 5 & 4 \\ \mathrm{DW}_{5} & 123 & 502 & 240 & 200 & 24 & 8 & 7 & 72 & 8 & 20 & \mathrm{ND} \\ \mathrm{BN}_{1} & 85 & 460 & 260 & 390 & 40 & 2 & 0.9 & 20 & 6 & 18 & 2 \\ \mathrm{BN}_{2} & 63 & 502 & 200 & 210 & 28 & 3 & 8 & 44 & 7 & 29 & \mathrm{ND} \\ \mathrm{BN}_{3} & 73 & 680 & 50 & 170 & 16 & \mathrm{ND} & 2 & 21 & 8 & 14 & 2 \\ \mathrm{BN}_{4} & 91 & 574 & 80 & 200 & 28 & \mathrm{ND} & 2 & 10 & 5 & 11 & 2 \\ \mathrm{BN}_{5} & 103 & 502 & 100 & 260 & 31 & 2 & 8 & 24 & \mathrm{ND} & 32 & \mathrm{ND} \\ \mathrm{BS}_{1} & 109 & 590 & 240 & 140 & 16 & 3 & 5 & 29 & 4 & 7 & \mathrm{ND} \\ \mathrm{BS}_{2} & 81 & 306 & 50 & 160 & 19 & 5 & 5 & 18 & 3 & 7 & 4 \\ \mathrm{BS}_{3} & 73 & 304 & 110 & 470 & 24 & 3 & 2 & 4 & 2 & 5 & \mathrm{ND} \\ \mathrm{BS}_{4} & 72 & 240 & 112 & 280 & 21 & \mathrm{ND} & 2 & \mathrm{ND} & 6 & 11 & 2\end{array}$

Table 1 Continued

\begin{tabular}{|c|c|c|c|c|c|c|c|}
\hline $\mathrm{BS}_{4}$ & Light reddish brown & 5 YR6/3 & Fine & 1.21 & 1.21 & 5.30 & 1.43 \\
\hline $\mathrm{BS} \mathrm{s}$ & Brown & 7.5 YR 4/4 & Coarse & 1.26 & 1.27 & 4.50 & 1.38 \\
\hline $\mathrm{BE}_{1}$ & Yellowish red & SYR 4/6 & Coarse & 1.51 & 1.55 & 5.10 & 1.82 \\
\hline $\mathrm{BE}_{2}$ & Light brown & 7.5 YR $6 / 4$ & Coarse & 1.47 & 1.50 & 5.20 & 1.28 \\
\hline $\mathrm{BE}_{3}$ & Strong brown & 7.5 YR 5/6 & Coarse & 1.51 & 1.54 & 5.50 & 0.60 \\
\hline $\mathrm{BE}_{4}$ & Strong brown & 7.5 YR 5/8 & Coarse & 1.56 & 1.62 & 4.90 & 0.55 \\
\hline $\mathrm{BE}_{5}$ & Strong brown & 7.5 YR 5/6 & Fine & 2.50 & 2.60 & 5.20 & 0.56 \\
\hline $\mathrm{BW}_{1}$ & Reddish yellow & 5 YR 6/5 & Gravel & 2.63 & 2.74 & 5.30 & 1.10 \\
\hline $\mathrm{BW}_{2}$ & Reddish brown & 5 YR 4/4 & Sandy & 1.72 & 1.67 & 4.90 & 1.29 \\
\hline $\mathrm{BW}_{3}$ & Strong brown & 7.5 YR $5 / 6$ & Coarse & 1.66 & 1.63 & 5.00 & 0.36 \\
\hline $\mathrm{BW}_{4}$ & Strong brown & 7.5 YR 5/8 & Coarse & 1.47 & 1.44 & 4.90 & 0.58 \\
\hline $\mathrm{BW}_{5}$ & Dark brown & 7.5 YR 4/4 & Fine & 1.96 & 1.90 & 5.90 & 0.59 \\
\hline $\mathrm{MN}_{1}$ & Light brown & 7.5 YR $6 / 5$ & Coarse & 1.85 & 1.88 & 5.50 & 1.16 \\
\hline $\mathrm{MN}_{2}$ & Brown & 7.5 YR $5 / 4$ & Coarse & 1.81 & 1.88 & 5.10 & 1.23 \\
\hline $\mathrm{MN}_{3}$ & Pink & 7.5 YR7/4 & Coarse & 2.08 & 2.12 & 6.80 & 0.42 \\
\hline $\mathrm{MN}_{4}$ & Light brown & 7.5 YR 6/4 & Coarse & 1.96 & 2.04 & 5.40 & 1.68 \\
\hline $\mathrm{MN}_{5}$ & Pink & 7.5 YR $8 / 4$ & Silt & 1.28 & 1.33 & 5.10 & 1.88 \\
\hline $\mathrm{MS}_{1}$ & Dark brown & 7.5 YR $6 / 3$ & Coarse & 1.42 & 1.48 & 5.40 & 0.81 \\
\hline $\mathrm{MS}_{2}$ & Light brown & 7. SYR $6 / 6$ & Coarse & 1.66 & 1.69 & 5.30 & 0.78 \\
\hline $\mathrm{MS}_{3}$ & Brown & 7.5 YR 5/2 & Coarse & 1.47 & 1.56 & 6.00 & 0.93 \\
\hline $\mathrm{MS}_{4}$ & Brown & 7.5 YR 5/4 & Coarse & 1.72 & 1.79 & 5.80 & 0.64 \\
\hline $\mathrm{MS}_{5}$ & Strong brown & 7.5 YR 5/8 & Gravel & 1.61 & 1.68 & 5.60 & 0.31 \\
\hline $\mathrm{ME}_{1}$ & Yellowish red & $5 \mathrm{YR} 5 / 6$ & Coarse & 1.66 & 1.71 & 6.70 & 0.51 \\
\hline $\mathrm{ME}_{2}$ & Light brown & 7,5 YR 6/4 & Coarse & 1.72 & 1.70 & 6.00 & 0.66 \\
\hline
\end{tabular}




\begin{tabular}{llll|llll}
$\mathrm{ME}_{3}$ & Weak red & $2.5 \mathrm{YR} 5 / 2$ & Gravel & 1.78 & & 6.90 & \\
$\mathrm{ME}_{4}$ & Light reddish brown & $5 \mathrm{YR} \mathrm{6/3}$ & Coarse & 1.69 & 1.72 & 6.40 & 1.04 \\
& & & & & & \\
$\mathrm{ME}_{5}$ & Dark brown & $7.5 \mathrm{YR} 4 / 4$ & Gravel & 1.72 & 1.91 & 5.40 & 0.57 \\
$\mathrm{MW}_{1}$ & Light reddish brown & $5 \mathrm{YR} \mathrm{6/4}$ & Coarse & 1.32 & 1.38 & 5.80 & 0.60 \\
$\mathrm{MW}_{2}$ & Reddish yellow & SYR 7/4 & Coarse & 1.47 & 1.52 & 6.10 & 0.58 \\
$\mathrm{MW}_{3}$ & Pinkish gray & $7.5 \mathrm{YR} 7 / 3$ & Coarse & 1.56 & 1.59 & 4.90 & 0.51 \\
$\mathrm{MW}_{4}$ & Strong brown & 7.5 YR 5/8 & Fine & 1.92 & 2.00 & 5.20 & 1.29 \\
$\mathrm{MW}_{5}$ & Light brown & 7.5 YR 6/4 & Coarse & 1.56 & 1.58 & 6.60 & 1.17 \\
\hline
\end{tabular}

\section{Discussion}

This project was designed to quantify the mineral elements of soils in three local government areas namely: Donga, Bali and MutumBiyu, Local government area respectively of Taraba State. The physical properties of the soils determined were colour, $\mathrm{pH}$, conductivity, density, and specific density and texture while chemical elements were $\mathrm{N}, \mathrm{K}, \mathrm{Na}, \mathrm{Ca}, \mathrm{Mn}, \mathrm{Pb}, \mathrm{Fe}, \mathrm{Zn}, \mathrm{Ni}, \mathrm{Cr}$ and $\mathrm{Cu}$.

The results of the physical properties were as present in Table 1.

The first letters in the sample codes refer to Donga (D), Bali (B) and Mutum-Biyu (M); the second letters refer to geographical direction and the number 1 to 5 sampling location along each direction

The colour results of the soil colour were as presented in Table 1 . Samples $\mathrm{DE}_{2}, \mathrm{DW}_{2}, \mathrm{DW}_{3}, \mathrm{BS}_{4}, \mathrm{BW}_{2}$ and $\mathrm{MS}_{1}$ were found to be reddish brown which suggest the presence of iron oxides with such colour, for example, haemitite is red while magnetite is brown in colour (Brady and Weil, 2002). Samples $\mathrm{DN}_{3}$ and $\mathrm{ME}_{3}$ showed weak red coloration and sample $\mathrm{BN}_{2}$, and $\mathrm{BN}_{3}$ light red colouration which were perhaps due to the presence of haemitite. Dark reddish brown colour of samples $\mathrm{DE}_{3}, \mathrm{DE}_{5}$ may be due to organic humus.

Samples $\mathrm{DW}_{2}, \mathrm{BS}_{5}, \mathrm{MN}_{2}, \mathrm{MS}_{4}, \mathrm{MS}_{3}$ showed brown colouration. Strong brown colouration was observed in sample $\mathrm{DW}_{5}, \mathrm{BN}_{7}, \mathrm{BS}_{2}$, $\mathrm{BE}_{3}, \mathrm{BE}_{4}, \mathrm{BE}_{5}, \mathrm{BW}_{3}$ and $\mathrm{BW}_{4}$. Sample $\mathrm{DN}_{1} \mathrm{DS}_{3}, \mathrm{DW}_{4}, \mathrm{BW}_{5}$ and $\mathrm{ME}_{5}$ showed dark brown colouration, $\mathrm{DE}_{2}, \mathrm{MN}_{4}, \mathrm{MS}_{2}, \mathrm{ME}_{2}$ and $\mathrm{MW}_{4}$ showed light brown colour while sample $\mathrm{BS}_{1}$, showed yellowish brown. These colours were perhaps due to the presence of brown colour of magnetite (Sakar et al., 2001).

Light reddish brown colouration was observed in samples $\mathrm{DN}_{2}, \mathrm{DS}_{2}, \mathrm{BN}_{4}, 684, \mathrm{ME}_{4}$ and $\mathrm{MW}_{1}$, while samples $\mathrm{BS}_{1}, \mathrm{BE}_{1}$ and $\mathrm{ME}_{1}$ showed, yellowish red and samples $\mathrm{DE}_{1}, \mathrm{BN}_{5}, \mathrm{BW}_{1}$ and $\mathrm{MW}_{2}$ showed reddish yellow colouration. These colours were perhaps due to the presence of haemitite and brown colour of haemitites, the yellow colour of goethite and the red colour of haemitite, and the presence of the red of magnetite and the yellow of goethite respectively. Pinkish gray colour was observed in sample $\mathrm{DN}_{4}$ and $\mathrm{BS}_{2}$ while samples $\mathrm{DE}_{4}$ showed reddish gray colourations which were due to the removal of free iron under reducing conditions (Brady, 2002).

The $\mathrm{pH}$ values of the soil samples were as given in Table 1. It ranged from 4.10 to 6.90. Samples $\mathrm{DN}_{1}$ and $\mathrm{ME}_{3}$ had the highest but same $\mathrm{pH}$ value of 6.90 , while sample $\mathrm{DN}_{5}$ with the lowest $\mathrm{pH}$ value of 4.10 . The ranges are within the acidic region. This shows that the soil samples from the three study area (Donga, Bali and Mutum-Biyu) were predominantly acidic in nature.

The conductivity values of the samples presented in Table 1 ranged soil sample from 0.31 x 103 to $2.20 \times 10 \sim 3 \mathrm{uS} / \mathrm{cm}$. The highest and lowest were found value, in samples $\mathrm{DN}_{4}$ and $\mathrm{MS}_{5}$, respectively. The high conductivity of the $\mathrm{DN}_{4}$ sample may be due to high concentrations of mobile ions or leached substances while the low conductivity value of sample $\mathrm{MS}_{5}$ may be due to low concentration of conducting ions.

The results of densities and specific gravities are shown on Table

1. The range of the soil sample density is from 1.12 to $2.63 \mathrm{~g} / \mathrm{cm} 3$ marked by samples $\mathrm{BS}_{3}$ and $\mathrm{BW}_{1}$ respectively. For specific gravity, the range for the soil samples were from 1.11 to 2.74 also marked by the same samples $\left(\mathrm{BS}_{3}\right.$ and $\left.\mathrm{BW}_{1}\right)$ respectively. Soils with densities and specific gravities above 1.7 may be sandy soils, in which organic matters are low or continuous tillage of land might have been experienced for longer time (Brady and Weil, 2002).

Soils with high densities have high compactibility which inhibits the easy penetration of roots to the ground and also does not permit movement of water easily on the soil (Kennedy, 1980).

The Calcium contents of the soil sample ranged from $70-470 \mathrm{mg} / \mathrm{kg}$ as compared to the magnesium range from $12-68 \mathrm{mg} / \mathrm{kg}$. The highest values for both calcium and magnesium were found in sample

$\mathrm{BS}_{3}(470 \mathrm{mg} / \mathrm{kg})$ and $\mathrm{MW}_{2}(68 \mathrm{mg} / \mathrm{kg})$ respectively. The sodium content ranged from 10-310 mg/kg while potassium ranged from 2$415 \mathrm{mg} / \mathrm{kg}$. The highest sodium value was obtained in sample $\mathrm{BS}_{5}, \mathrm{BE}_{5}$ and $\mathrm{MW}_{5}$. 
Sodium was not detected in samples $\mathrm{DE}_{2}, \mathrm{DW}_{2}, \mathrm{DW}_{3}, \mathrm{BE}_{2}$ and $\mathrm{BE}_{4}$. Potassium was not detected in samples $\mathrm{BW}_{4}$ and $\mathrm{BW} 5$ only while manganese was not-detected in samples $\mathrm{DE}_{2}, \mathrm{DE}_{3}, \mathrm{BN}_{3}, \mathrm{BN}_{5}, \mathrm{BW}_{2}, \mathrm{BW}_{5}, \mathrm{MN}_{2}, \mathrm{MN}_{3} \mathrm{ME}_{2}, \mathrm{ME}_{3}$ and $\mathrm{MW}_{5}$. Lead was not detected in $\mathrm{MN}_{1}, \mathrm{MN}_{2}, \mathrm{MW}_{3}$ and $\mathrm{MW}_{5}$,

Copper was not detected in any of the samples analysed. Chromium was not detected in most of the samples namely samples but found only in samples $\mathrm{MW}_{5}(14 \mathrm{mg} / \mathrm{kg}), \mathrm{MW}_{4}(13)$ and $\mathrm{BE}_{3}, \mathrm{DN}_{5}, \mathrm{DE}, \mathrm{DW}_{4}$ and $\mathrm{BS}_{2}(4 \mathrm{mg} / \mathrm{kg})$. The lowest detectable concentration was $2 \mathrm{mg} / \mathrm{kg}$ found in $\mathrm{MW}_{3}, \mathrm{ME}_{1}, \mathrm{MS}_{5}, \mathrm{DE}_{5}, \mathrm{DE}_{2}, \mathrm{DS}_{2}$ and $\mathrm{DN}_{1}$

The iron concentration for Donga soil samples $\left(\mathrm{DN}_{1}-\mathrm{DN}_{5}\right)$ ranged from 3 to $72 \mathrm{mg} / \mathrm{kg}$; the highest and lowest value in $\mathrm{DW}_{5}$ and $\mathrm{DW}_{2}$, respectively.

The value for Bali soils $\left(\mathrm{BN}_{1}-\mathrm{BW}_{5}\right)$ ranged from 4 to $96 \mathrm{mg} / \mathrm{kg}$. The highest and lowest values were found in $\mathrm{BW}_{5}$ and $\mathrm{BS}_{3}$ but $\mathrm{BS}_{4}$ and $\mathrm{BW}_{5}$ samples did not show detectable amount of the metal. The Mutum-Biyu $\left(\mathrm{MN}_{1}-\mathrm{MW}_{5}\right)$ values ranged from 8 to 47 uni.ts with the highest and lowest

detectable values in $\mathrm{MN}_{1}$ and $\mathrm{MS}_{2}$ respectively. The range values for $\mathrm{Zn}$, etc are shown in Table 2.

The order of contents of the metals in the study area is $\mathrm{Fe}>\mathrm{Ni}>\mathrm{Zn}>\mathrm{Cr}>\mathrm{Cu}$.

In terms of the three Local Government Areas studied, the orders are

a) $\quad$ Fe: Bali > Donga > Mutum-Biyu

b) Zn: Donga $>$ Bali and Mutum-Biyu

c) Ni: Bali $>$ Mutum-Biyu $>$ Donga

d) Cr: Mutum-Biyu $>$ Donga $>$ Bali

e) $\quad \mathrm{N}$ : Donga $>$ Bali $>$ Mutum-Biyu

f) $\quad \mathrm{K}:$ Donga $>$ Bali $>$ Mutum-Biyu

g) Na: Donga $>$ Bali $>$ Mutum-Biyu

h) $\quad$ Mg: Mutum-Biyu $>$ Bali $>$ Donga

i) $\quad$ Mn: Donga $>$ Bali $>$ Mutum-Biyu

j) $\quad \mathrm{Pb}$ : Bali $>$ Donga $>$ Mutum-Biyu

Bali study area had the highest contents of $\mathrm{Fe}, \mathrm{Pb}$ and $\mathrm{Ni}$ but the least value of $\mathrm{Cr}$.

\section{Conclusion}

Results of the soil sample analyses showed the presence of $\mathrm{Fe}, \mathrm{Zn}, \mathrm{Ni}, \mathrm{Cr}, \mathrm{N}, \mathrm{K}, \mathrm{Na}, \mathrm{Mg}, \mathrm{Mn}$ and $\mathrm{Pb}$ respectively. Only Cu was not detected in any of the soil samples. The results showed, a decreasing order: $\mathrm{K}>\mathrm{Ca}>\mathrm{Na}>\mathrm{N}>\mathrm{Fe}>\mathrm{Mg}>\mathrm{Mn}>\mathrm{Ni}>\mathrm{Cr}>\mathrm{Pb}$. Also, the colours of the soil samples were between brown, red and yellow suggesting high iron contents. The $\mathrm{pH}$ values of the soil samples ranged from 4.10 to 6.90 and indicate them to be acidic with the highest value in samples $\mathrm{DN}_{1}$ and $\mathrm{ME}_{3}$ while the lowest value in $\mathrm{DN}_{5}$. pH 4.10 to 6.90 shows that soil samples from Donga, Bali and Mutum-Biyu are predominantly acidic in nature. Soil $\mathrm{pH}$ ranges of 5.5 to 6.5 perhaps 7.0 provide most satisfactory plant nutrients level overall (Brady, 2002). pH below 5.5 is said to be toxic to plant. By implication, it means the studied areas, with $\mathrm{pH} 4.10$ to 6.90 , are productive in terms of $\mathrm{pH}$ for the growth of crops.

\section{Acknowledgement}

Authors acknowledge the support of all the local farmers in Donga, Bali and Mutum-Biyu Local Government Areas

\section{References}

[1] Anyakoha, M.W. (1999) 'New School Physics, Africa Publisher Ltd, Onitsha, Nigeria, p 150-152.

[2] Association of Official Agricultural Chemist, AOAC (1970), 'Official Methods of Analysis5, Macmillan Publishers Ltd, London, U.K. P95, 250-257.

[3] Brady, N.C. (2000), The Nature and Properties of Soil5, Low Price Ed., Twelfth Ed., Pearson Education Inc. Singapore, P1820,122-133,

[4] Brewer, R. (1964), 'Fabric and Mineral Analysis of Soil5, John Wiley and Sons Ltd., New York, U.S.A. P.172-174.

[5] Brevik, E.C. (2002), 'Soil Classification in Geology Textbook5, Journal of Geosciences Education 50:539.

[6] Bigham, J.M. and Ciolkosz, E.J. (Ed.), 1993. 'Soil Colour5, Special Publication No. 31, Madison, Soil Science Society of America.

[7] Britannica Encyclopaedia (2006), Soil Chemistry. Retrieved on Website www.Britannica.com. 15/12/2006.

[8] Buol, S.W., Hole, F.D. \& M $^{\circ}$ cracken, R.J. (1973), 'Soil Genesis and Classification5, First Amen Inc. Iowa State University Press. P140-141

[9] Burns, R.C. and Hardy, R.W.F. (1975), 'Nitrogen Fixation in Bacteria and Higher Plants, Springer-Verlag Ltd. Berlin, Germany p 60-61

[10] Cogger, C. and Duxxbury, J.M. (1984), 'Factors Affecting Loss from Cultivated Organic Soils5, Journal on Environmentals. 13: $111-114$.

[11] De Angelis (1975), 'Pedriatric Primary care5, 2nd Edition, little Brown and co. Inc. London P 200. 
[12] Dokuchaev, V.V. Retrieved on http://wikipedia.org. 12/15/2006, P.6 of 8.

[13] Onifiok, O.E. (1985), 'Soil Classification Relationship in Enugu, 1st Edition, Academic Press, Enugu, Nigeria p 18-20.

[14] Parker, S. (1997), 'Encyclopaedia of Science and Technology,' 8th Edition. Vol. 2, 4, 16, 17 and 18. Mc Graw-Hill companies. USA P 120, 189, 198-199, 453-454, 468-470, 698.

[15] Pielke, R. (2005) 'Is Soil an Important Component of the Climate System?' http://en.wikipredia.org. Retrieved 12/15/2006 P.1 of 8 .

[16] Pomeranz, Y. and Clinton, E. (1987), 'Food Analysis Theory and Practice,' 2nd Edition. Van Nostrand Reinhold. USA P 67.

[17] Rijsberman, F.R and Wolman, M.G. (1984), 'Effect of Soil Erosion and Soil Productivity Soils', Inc. Comparison on Soil and Water Conservation. Halsted Press, New York, U.S.A. Pp 110-112.

[18] Sakar, J.P, Landey, R.J., Kalbande, A.R and Mandol, C. (2001), Characteristics and Classification of Soils of Kathiawar Region of Gurarat as Influenced by Topography. Agropedology, Journal of Soil Science, A.B.U Zaria, Nigeria Pp 83-90.

[19] Seubert, C.E., Sanchez, B. and Valvarde, C. (1977), 'Effects of Land Clearing Methods on Soil Properties on an Utisol and Crop Performance in Amazon Jungle of Peru. Tropical Agriculture (Trinidad) Pp. 307-321. 